\title{
Vores demokrati er virkelig en bekymring værd!
}

\section{- en kommentar til Lisbeth Knudsens kommentar "Danskerne er bekymrede for demokratiets tilstand"}

\author{
Af Jørn Helder *)
}

I Altinget den 14. maj 2021 præsenterer Lisbeth Knudsen i en kommentar det internationale demokratiindeks Democracy Perception Index 2021, som er udført af et globalt markedsanalysefirma, Latana, i samarbejde med Alliances of Democracies under overskriften "Danskerne er bekymrede for demokratiets tilstand". Hun gennemgår hovedresultaterne fra undersøgelsen og konkluderer i forhold til Danmarks acceptable placering, at der stadig udestår nogle ikke ubetydelige demokratiske problemer, da der ifølge undersøgelsen er $20 \%$ af de interviewede danskere, som ikke er tilfredse med demokratiets tilstand herhjemme, ligesom mellem 30-50\% ser trusler i forhold til demokratiet. Dette får hende til at råbe vagt i gevær:

Men på det nationale plan er der behov for at tage nogle af advarslerne og befolkningens bekymringer for demokratiet alvorligt. Vi bør være et demokratisk foregangsland, hvor befolkningen ikke bekymrer sig om demokratiets forudsætninger som ytringsfrihed, frie og uafhængige valg og lige muligheder til at deltage er truet. Forhåbentligt vil den kommende nye magtudredning tage de perspektiver med i sit arbejde.

Denne advarsel tilskrives resultaterne af forskellige forhold, som indekset oplister: Økonomisk ulighed, manglende ytringsfrihed, tech-giganternes magt og indflydelse, debattilstanden på de sociale platforme, tvivl om valghandlinger nu også er fair og retvisende, risiko for fremmed indblanding i valghandlinger og endelig frygt for udviklingen i den globale politik.

*) Jørn Helder er cand. mag, ph.d.- tidligere lektor og ekstern lektor 
Det er naturligvis uhyre vigtigt løbende at konfrontere demokratiet, for at undgå at demokratiske processer sander til og blot bliver ureflekterede praksisser, hvor vi fx ved festlige lejligheder kan betragte os selv i Grundlovens spejl og med en vis tilfredshed konstatere, at det går jo meget godt, når det gælder demokratiet - måske fordi vi gennemgående opfatter demokrati og parlamentarisme som noget selvfølgeligt. Men ingen af delene er selvfølgelige. De demokratiske muskler skal fortløbende trænes og holdes i form, hvilket kun kan ske gennem en aktiv indsats og konfrontation med de demokratiske tiltag og beslutninger, der sker. Vi er i al enkelhed nødt til at fokusere på demokratiets værdier og en ideel praksis for at beholde det. Passivitet vil blot indsnævre det demokratiske rum og reducere vores indflydelse.

Om man kan måle og skalere et demokrati, er naturligvis et spørgsmål. Umiddelbart kan det forekomme vanskeligt, hvis man ikke opstiller absolutte kriterier for hvad et demokrati er, hvilket i sagens natur næppe er muligt med de mange forskellige udgaver af demokrati, der eksisterer.

Man kan måle kvantitativt eller kvalitativt. En kvantitativ tilgang vil typisk operere med absolutte størrelser og har som mål at generere nogle mere eller mindre universelle lovmæssigheder. I modsætning hertil står en kvalitativ tilgang, som jo i stedet kan præstere et resultat, der kommunikerer det opfattede demokrati hos respondenterne, hvilket genererer viden om respondenters livsverden, der uanset mængden af data ikke kan præsentere en universel lovmæssighed om demokrati og/eller intensiteten af demokrati.

Denne distinktion deles tilsyneladende ikke af Alliances of Democracies, der nævnt en passant har Anders Fogh Rasmussen (tidligere Venstre-statsminister), Fritz Schur (finansmand) og Klaus Søgaard (partner i Gorrissenfederspiel) i bestyrelsen, idet deres undersøgelsesmetode har været kvalitativ, hvorefter de alligevel fremlægger resultaterne som tilnærmelsesvise lovmæssigheder.

De har ifølge deres egen metodebeskrivelse gennemført 53.194 on-line interviews i perioden 24 . februar og 14. april 2021 i 53 forskellige lande med en gennemsnitlig population på 1000 respondenter pr. land, idet der ifølge deres eget udsagn var repræsentativ fordeling af alder, køn og uddannelsesniveau i hvert enkelt land.

Alliances of Democracy definerer sig selv på deres hjemmeside som:

The Alliance of Democracies Foundation is a non-profit organization founded in 2017 by Anders Fogh Rasmussen, the former NATO Secretary General and former Prime Minister of Denmark. The vision of the Alliance of Democracies Foundation is to become the world's leading "megaphone" for the cause of democracy. 
Deres mål er at sikre demokrati, som de ser det, beskrevet i afsnittet "Hvorfor kæmpe for demokrati?" (min oversættelse), der er karakteriseret ved: Since the end of World War II, the United States and its allies in Europe and Asia have established an international order dominated by democracy and market-based economies. Denne kamp er nødvendig, fordi Alliances of Democracies oplever, at demokratier er under stadig stigende pres fra forskellig side bl.a. fra terrororganisationer, autokratier etc.

Dette er naturligvis en sympatisk tanke at forsvare demokratiet, men det skal samtidig pointeres, at det jo kun er en enkelt version af demokratiet, der screenes af Allances of Democracies.

Der findes ganske mange forskellige versioner og varianter af demokrati, hvorfor en indkredsning af begrebet naturligvis indledningsvis er nødvendigt. Man kunne fx begynde med at konsultere Den Danske Ordbog, hvor demokrati defineres som "en styreform hvor den voksne del af befolkningen øver politisk indflydelse gennem folkeafstemninger eller valg af repræsentanter til politiske forsamlinger, mens mindretalsrettigheder sikres gennem bl.a. ytrings- og forsamlingsfrihed." Denne definition er dog heller ikke fyldestgørende, da definitionen dels primært adresserer det repræsentative demokrati dels yderlig synonymiserer parlamentarisme med demokrati. Hvis man dykker blot en anelse dybere, kan man konstatere, at der eksisterer flere udgaver af demokrati ud over det repræsentative demokrati, fx ifølge Løhmann semi-direkte demokrati, deliberativt demokrati etc.

Det repræsentative demokrati er som oftest et partibaseret politisk system, hvor en befolkning gennem regelmæssige valghandlinger kan vælge opstillede kandidater til at træffe beslutninger og vedtage love. Semi-direkte demokrati, der kan karakteriseres som en blanding af repræsentativt demokrati og folkeafstemninger kendes bedst fra Schweiz. Endelig er det deliberative demokrati som er et demokrati, der konstitueres af en demokratisk dialog i offentligheden, som både den tyske sociolog Jürgen Habermas og den danske Hal Koch er markante eksponenter for.

Specielt Habermas har argumenteret for dialogen, eller det han karakteriserer som den herredømmefri samtale, som essensen af en demokratisk beslutningsproces. Han har opstillet ideelle regler - en diskursetik - for, hvordan dialogen skal foregå. Habermas argumenterer således for, at vi gennem dialogen kan nå det bedst mulige resultat eller konsensus (ikke kompromis), som han benævner det.

Habermas definerer diskursen som en dialog om et givet udsagn med konsensus som mål i forhold til gyldigheden af dette udsagn. Udgangspunktet for dialogen (diskursen) er en påstand omkring et emne fremført af en af dialogdeltagerne med det formål at få afprøvet gyldigheden af den givne 
påstand. Formålet er som nævnt at opnå konsensus omkring det bedste argument, således at det $\mathrm{i}$ slutningen af dialogen fremstår som modsigelsesfrit, dvs. når alle deltagere i dialogen er enige om at mene det samme og yderligere accepterer både argumentationens og argumenternes styrke (Helder, 2018).

Ud over de allerede nævnte demokratiformer findes der ganske mange flere. Men helt basalt med definitionernes fokus på folket er der indbygget et imperativ om at deltage i at sikre demokratiet (forudsat man anser det for den rigtigste måde at indrette samfundet på). Man skal således ikke eksempelvis med baggrund i den ovenfor citerede undersøgelse blot læne sig veltilfreds tilbage. Det kan unægtelig undre, at ikke flere engagerer sig aktivt i kampen for demokratiet, hvis der, som Knudsen skriver, er mellem 30-50 procent danskere, som ser trusler for sig i forhold til demokratiet, hvilket accentueres yderligere af den passivitet og mangel på demokratiske krav, vi har været vidne til under corona-krisen, hvor tilsidesættelse af demokratiske og borgerlige rettigheder blev dagligdag med henvisning til bekæmpelse af sygdommen. Et forhold, Lisbeth Knudsen adresserede i sin artikel i Altinget fra den 2. oktober 2020: "Vi kan ikke leve med et demokrati på pause, når krisen rammer", hvor hun efter at have stillet spørgsmålstegn ved forskellige beslutningers legitimitet afslutningsvis skriver:

Derfor har vi brug for en mere grundlæggende samtale om, hvordan vores demokratiske strukturer kan gøres mere robuste og i stand til at håndtere en krise i fremtiden, som kræver lynhurtige, modige og konsistente beslutninger.

Vi burde ikke kunne leve med et demokrati sat på pause selv i en uhyggelig svær krisesituation. Vi har brug for en samtale om, hvad der skal til at strukturer for at kunne foretage kritisk, saglig efterprøvning af beslutningerne både i medierne og blandt eksperterne [sic]. Her var adgangen til informationer og data på ingen måde tilfredsstillende.

Det duer ikke med et demokrati, der kun fungerer i normale tider. Det skal også kunne fungere i massivt stormvejr og under kommende kriser.

Vi skal have den demokratiske dialog i centrum både for at undgå den demokratiske erosion, som Habermas advarer mod, hvor ubalancen mellem stat og offentlighed bliver mere og mere usynlig og derfor vanskeligere og vanskeligere at gennemskue - og for at sikre demokratiets overlevelse. Vi skal engagere os og forlange den demokratiske dialog, der af den danske teolog og filosof Løgstrup (ligesom både Habermas og Koch) beskrives som en skikkelig måde at være uenig på - og gennem uenighedens dynamik bidrage til at sikre demokratiet også for fremtiden. 


\section{Referencer}

Democracy Perception Index 2021 (Alliances of Democracies)

Helder, Jørn. (2018). ”Et spøgelse går gennem Europa - igen (Samfundslederskab i Skandinavien Årgang 33, Nummer 5, s. 459-487) https://doi.org/10.22439/sis.v33i5.5629

Knudsen. Lisbeth. (2020). "Vi kan ikke leve med et demokrati på pause, når krisen rammer" (Altinget)

Knudsen, Lisbeth. (2021). "Danskerne er bekymrede for demokratiets tilstand" (Altinget)

Løhmann Stephensen, Jan. (2015). Demokratisk deltagelse - forskellige former for demokrati, forskellige former for deltagelse (Århus Universitet) 